$\underline{\text { Original Article }}$

\title{
IN VITRO ANTIDIABETIC POTENTIALS OF SIDA ACUTA, ABUTILON INDICUM AND MALVASTRUM COROMANDELIANUM
}

\author{
NANTAPORN DINLAKANONT'1 ${ }^{1}$ CHANIDA PALANUVEJ ${ }^{1 *}$, NIJSIRI RUANGRUNGSI ${ }^{1,2}$ \\ ${ }^{1}$ College of Public Health Sciences, Chulalongkorn University, Bangkok 10330, Thailand, ${ }^{2}$ College of Pharmacy, Rangsit University, Pathum \\ Thani 12000, Thailand \\ Email: chanida.p@chula.ac.th
}

Received: 17 Mar 2020, Revised and Accepted: 14 May 2020

\section{ABSTRACT}

Objective: Starch metabolizing enzyme inhibitors are able to retard postprandial glucose absorption. This study aimed to investigate the in vitro inhibitory activities of alpha-glucosidase and alpha-amylase of three Malvaceous weeds i.e. Sidaacuta Burm. f., Abutilon indicum (Linn.) Sweet and Malvastrumcoromandelianum (Linn.) Garcke.

Methods: The stems, roots and leaves of S. acuta, A. indicum and M. coromandelianum were sequentially extracted in dichloromethane and methanol, respectively. All fractions were tested for the inhibitory activities on yeast alpha-glucosidase, rat intestinal alpha-glucosidase and porcine alpha-amylase. pNitrophenyl- $\alpha$-D-glucopyranoside and 2-chloro-4 nitrophenol- $\alpha$-D- maltotrioside were used as the substrate for glucosidase and amylase respectively.

Results: The dichloromethane fraction of the roots and stems from $A$. indicum and dichloromethane as well as methanolic fractions of the stems of M. coromandelianum could inhibit yeast alpha-glucosidase compared to 1-deoxynojirimycin with the $\mathrm{IC}_{50}$ of $0.36,0.45,0.48,0.48$ and $0.58 \mathrm{mg} / \mathrm{ml}$ respectively. A. indicum root methanolic fraction had the highest inhibitory effect on rat alpha-glucosidase activity compared to 1-deoxynojirimycin with the $\mathrm{IC}_{50}$ of 0.08 and $0.11 \mathrm{mg} / \mathrm{ml}$ respectively. $M$. coromandelianum, the dichloromethane fraction of roots and the methanolic fraction of stems, showed the strongest effect on alpha-amylase inhibition compared to acarbose with the $\mathrm{IC}_{50}$ of $0.07,0.07 \mathrm{and} 2.7 \mathrm{mg} / \mathrm{ml}$, respectively.

Conclusion: S. acuta, A. indicum and M. coromandelianum dichloromethane and methanolic fractions of the root, stem and leaf parts demonstrated an appreciable inhibitory activity on alpha-amylase from porcine, alpha-glucosidase from Saccharomyces cerevisiae and from rat intestine compared to 1-deoxynojirimycin and acarbose.

Keywords: Alpha-amylase, Alpha-glucosidase, Enzyme inhibition, Malvaceous weed

(c) 2020 The Authors. Published by Innovare Academic Sciences Pvt Ltd. This is an open access article under the CC BY license (http://creativecommons.org/licenses/by/4.0/) DOI: http://dx.doi.org/10.22159/ijcpr.2020v12i4.39088. Journal homepage: https://innovareacademics.in/journals/index.php/ijcpr

\section{INTRODUCTION}

After meal ingestion, the digestion of Starchbeginsfirstly by salivary $\alpha$ amylase and pancreatic $\alpha$-amylase to produce maltose, maltotriose and $\alpha$-limit dextrin which are further completely hydrolysed to glucose by $\alpha$ glucosidases in the brush border of intestinal epithelial cells or enterocytes [1]. The inhibition of $\alpha$-glucosidases as well as $\alpha$-amylase is one of the powerful interventions to decrease glucose absorption. Natural or synthetic $\alpha$-glucosidase inhibitors are of therapeutic interest to delay postprandial hyperglycemia in type 2 diabetes. Sidaacuta Burm. $\mathrm{f}$. is a Malvaceous weed cosmopolitan in distribution, especially in tropics and sub-tropics. It is commonly found on abandoned areas i.e. roadsides and wastelands. The leaf, root, and whole plant have been ethnomedicinally used for treatments of wound, dysentery, helminthiasis, hemorrhoid and malarial fever [2]. Arya et al. reported that $S$. acuta leaf alcoholic extract exhibited a slight decrease in blood glucose levels after 2 and $4 \mathrm{~h}$ of oral administration in normal rats [3]. Okwuosa et al. found that the aqueous extract and methanolic extract of $S$. acuta leaves significantly increased the tolerance for glucose in glucose fed normal rabbits and also decreased blood glucose of alloxan-induced diabetic rabbits [4]. Furthermore, Abutilon indicum (Linn.) Sweet and Malvastrumcoromandelianum (Linn.) Garckeare another Malvaceous weeds previously reported of the hypoglycemic potential in animal model [5-7]. This study aimed to investigate in vitro inhibitory activities on the starch digesting enzymes of the fractional extracts of the roots, leaves and stems of $S$. acuta, A. indicum and M. coromandelianum, the Malvaceous weeds used in traditional medicine.

\section{MATERIALS AND METHODS}

\section{Chemicals}

Rat intestinal acetone powders, Saccharomyces cerevisiae alphaglucosidase, porcine pancreatic $\alpha$-amylase, p-nitrophenyl- $\alpha$-D- glucopyranoside, 2-chloro-4 nitrophenol- $\alpha$-D-maltotrioside, 1deoxynojirimycin and acarbose were obtained from Sigma-Aldrich, USA. The chemicals were analytical grade. The ultrapure water was prepared by Ultra-pure water purification system, Heal Force, China.

\section{Plant collection}

S. acuta, $A$. indicum and M. coromandelianum were authenticated by Nijsiri Ruangrungsi. Voucher specimens (ND/PH/300115, $\mathrm{ND} / \mathrm{PH} / 300215$ and ND/PH/300315) were deposited at College of Public Health Sciences, Chulalongkorn University, Thailand. After sorting out any foreign matters, the stems, roots and leaves were dried in hot air oven at $50^{\circ} \mathrm{C}$ then pulverized for extraction.

\section{Plant extraction}

The stems, roots and leaves of $S$. acuta, A. indicum and $M$. coromandelianum were exhaustively extracted with dichloromethane and methanol respectively using Soxhlet apparatus. The fractional extracts were filtered through Whatman number 1 filter paper then evaporated to dryness in vacuo. The extracts were dissolved in $10 \%$ DMSO and diluted with water to obtain concentrations of $0.625-10 \mathrm{mg} / \mathrm{ml}$.

\section{Yeast alpha-glucosidase inhibition assay}

The activity of alpha-glucosidase from Saccharomyces cerevisiae was assayed using $1 \mathrm{mmol}$ of p-nitrophenyl- $\alpha$-D-glucopyranosideas substrate. The reaction mixture including $50 \mu \mathrm{l}$ of $0.1 \mathrm{M}$ sodium phosphate buffer (pH 6.9), $50 \mu \mathrm{l}$ of the substrate, $50 \mu \mathrm{l}$ of sample and $50 \mu \mathrm{l}$ of $\alpha$-glucosidase $(0.5 \mathrm{U} / \mathrm{ml})$ was incubated at $37^{\circ} \mathrm{C}$ for $20 \mathrm{~min}$ then added with $100 \mu \mathrm{l}$ of $1 \mathrm{M}$ sodium carbonate to stop the reaction. Enzymatic activity was quantified by measuring the absorbance of $p$ nitrophenol at $405 \mathrm{~nm}$. 1-Deoxynojirimycin was used as positive control. Each test was done in triplicate. 


\section{Rat intestinal alpha-glucosidase inhibition assay}

Thirty milligrams of rat intestinal acetone powders were suspended in $1 \mathrm{ml}$ of $0.1 \mathrm{M}$ sodium phosphate buffer ( $\mathrm{pH}$ 6.9), sonicated for 20 min and centrifuged at $3000 \mathrm{rpm}$ for $30 \mathrm{~min}$. The supernatant was used as $\alpha$-glucosidase enzyme. The reaction mixture consisted of $100 \mu \mathrm{l}$ of $1 \mathrm{mmol}$ of $\mathrm{p}$-nitrophenyl- $\alpha$-D-glucopyranoside as substrate, $50 \mu \mathrm{l}$ of sample and $50 \mu \mathrm{l}$ of the enzyme. The mixture was incubated at $37{ }^{\circ} \mathrm{C}$ for $30 \mathrm{~min}$. The absorbance was measured at $405 \mathrm{~nm}$. All tests were done in triplicate. 1-Deoxynojirimycin was used as a positive control. Each test was done in triplicate.

\section{Porcine alpha-amylase inhibition assay}

The activity of porcine pancreatic $\alpha$-amylase inhibition was performed on 96 well plates using 1 mmol of 2-chloro-4 nitrophenol- $\alpha-\mathrm{D}$-maltotrioside as substrate. Various concentrations of $S$. acuta, $M$. coromandelianum and A. indicum fractional extracts $(50 \mu \mathrm{l})$ were added into $0.5 \mu \mathrm{l}$ of $0.5 \mathrm{U} / \mathrm{ml}$ of porcine pancreatic $\alpha$-amylase prepared in $0.1 \mathrm{M}$ sodium phosphate buffer $\mathrm{pH}$ 6.9. The plate was preincubated at room temperature for $10 \mathrm{~min}$ and $50 \mu \mathrm{l}$ of substrate were added into each well and incubated at $37{ }^{\circ} \mathrm{C}$ for $20 \mathrm{~min}$. The absorbance was measured at $405 \mathrm{~nm}$. Each test was done in triplicate. Acarbose was used as a positive control.

\section{Enzyme inhibitory activity calculation}

The enzyme inhibitory activity was calculated from the absorbance of p-nitrophenol liberated at $405 \mathrm{~nm}$ with and without the inhibitor.

Inhibition $(\%)=\left(1-\mathrm{A}_{405}\right.$ Inhibitor $/ \mathrm{A}_{405} \mathrm{Negative}$ Control $) \times 100$

IC 50 values denoted the concentration of sample required to inhibit $50 \%$ of enzyme activity.

\section{RESULTS}

The fractional extracts of the stems, roots and leaves of three selected Malvaceous plants were performed by dichloromethane and methanol, respectively. The percent yields were shown in table 1 .

Table 1: Extract yield from selected malvaceous plants

\begin{tabular}{|c|c|c|c|}
\hline \multirow[t]{2}{*}{ Plant } & \multirow[t]{2}{*}{ Part used } & \multicolumn{2}{|l|}{ Yield (g/100g) } \\
\hline & & DCMa fraction $^{a}$ & $\mathbf{M}^{\mathbf{b}}$ fraction \\
\hline \multirow[t]{3}{*}{ Sidaacuta Burm. f } & Stem & 3.93 & 12.55 \\
\hline & Root & 1.46 & 4.62 \\
\hline & Leaf & 1.65 & 21.43 \\
\hline \multirow[t]{3}{*}{ Abutilon indicum (Linn) Sweet. } & Stem & 1.34 & 8.20 \\
\hline & Root & 3.07 & 25.90 \\
\hline & Leaf & 1.60 & 15.40 \\
\hline \multirow[t]{3}{*}{ Malvastrumcoromandelianum (L.) Garcke. } & Stem & 3.50 & 13.15 \\
\hline & Root & 3.48 & 13.00 \\
\hline & Leaf & 9.08 & 24.12 \\
\hline
\end{tabular}

aDichloromethane bMethanol

Table 2: IC 50 of $S$. acuta, $A$. indicum, $M$. coromandelianum extracts on yeast and rat alpha-glucosidase inhibition

\begin{tabular}{|c|c|c|c|c|c|}
\hline \multirow[t]{3}{*}{ Plant } & \multirow[t]{3}{*}{ Part used } & \multicolumn{4}{|l|}{$\mathrm{IC}_{50}(\mathrm{mg} / \mathrm{ml})$} \\
\hline & & \multicolumn{2}{|c|}{ Yeast alpha-glucosidase } & \multicolumn{2}{|c|}{ Rat intestinal alpha-glucosidase } \\
\hline & & DCM $^{a}$ fraction & $M^{\mathbf{b}}$ fraction & DCMa fraction $^{a}$ & $\mathbf{M}^{\mathbf{b}}$ fraction \\
\hline \multirow[t]{3}{*}{ Sidaacuta Burm. f } & Stem & 1.56 & 5.88 & 3.03 & 2.53 \\
\hline & Root & 1.46 & 8.12 & 3.96 & 1.08 \\
\hline & Leaf & 1.66 & 2.38 & 2.43 & 0.19 \\
\hline \multirow[t]{3}{*}{ Abutilon indicum (Linn) Sweet. } & Stem & 0.45 & 1.69 & 4.67 & 1.11 \\
\hline & Root & 0.36 & 1.38 & 3.19 & 0.08 \\
\hline & Leaf & 1.07 & 4.21 & 2.69 & 1.38 \\
\hline \multirow{3}{*}{ Malvastrumcoromandelianum (L.) Garcke. } & Stem & 0.48 & 0.48 & 6.50 & 1.35 \\
\hline & Root & 0.71 & 0.74 & 0.90 & 1.88 \\
\hline & Leaf & 1.07 & 1.70 & 1.55 & 3.61 \\
\hline 1-Deoxynojirimycin & & 0.58 & & 0.11 & \\
\hline
\end{tabular}

aDichloromethane ${ }^{\mathrm{b}}$ Methanol

Table 3: IC 50 of $S$, acuta, $A$. indicum, M. coromandelianum extracts on alpha-amylase inhibition

\begin{tabular}{|c|c|c|c|}
\hline \multirow[t]{2}{*}{ Plant } & \multirow[t]{2}{*}{ Part used } & \multicolumn{2}{|l|}{$\mathrm{IC}_{50}(\mathrm{mg} / \mathrm{ml})$} \\
\hline & & DCM $^{a}$ fraction & $\mathrm{M}^{\mathrm{b}}$ fraction \\
\hline \multirow[t]{3}{*}{ Sidaacuta Burm. f } & Stem & 1.71 & 2.65 \\
\hline & Root & 0.33 & 0.66 \\
\hline & Leaf & 1.88 & 2.08 \\
\hline \multirow[t]{3}{*}{ Abutilon indicum (Linn) Sweet. } & Stem & 1.97 & 1.35 \\
\hline & Root & 0.90 & 1.89 \\
\hline & Leaf & 1.55 & 3.61 \\
\hline \multirow[t]{3}{*}{ Malvastrumcoromandelianum (L.) Garcke. } & Stem & 2.12 & 0.07 \\
\hline & Root & 0.07 & 0.28 \\
\hline & Leaf & 0.81 & 1.71 \\
\hline Acarbose & & 2.7 & \\
\hline
\end{tabular}

aDichloromethane bMethanol 
The yeast and rat intestinal alpha-glucosidase inhibition of the fractional extracts $(0.625-10 \mathrm{mg} / \mathrm{ml})$ and 1 -deoxynojirimycin $(0.03$ $1.5 \mathrm{mg} / \mathrm{ml}$ ) were demonstrated in table 2 . All of the extracts could inhibit yeast alpha-glucosidase activity especially the dichloromethane fraction of the roots and stems from A. indicum and also dichloromethane as well as methanolic fractions of the stems of $M$. coromandelianum. They showed the strong inhibitory effect on yeast alpha-glucosidase compared to 1-deoxynojirimycin with the $\mathrm{IC}_{50}$ of $0.36,0.45,0.48,0.48$ and $0.58 \mathrm{mg} / \mathrm{ml}$ respectively. The inhibitory activities against rat intestinal alpha-glucosidase were shown that $A$. indicum root methanolic fraction had the highest inhibitory effect on rat alpha-glucosidase activity compared to 1deoxynojirimycin with the $\mathrm{IC}_{50}$ of 0.08 and $0.11 \mathrm{mg} / \mathrm{ml}$, respectively. The dichloromethane fraction of $M$. coromandelianum stems showed the weakest effect with the $\mathrm{IC}_{50}$ of $6.50 \mathrm{mg} / \mathrm{ml}$. All of the extracts inhibited alpha-amylase activity, especially the dichloromethane fraction of $M$. coromandelianum roots and methanolic fraction of $M$. coromandelianum stems. They showed the strongest effect on alphaamylase inhibition compared to acarbose with the IC50 of 0.07, 0.07 and $2.7 \mathrm{mg} / \mathrm{ml}$, respectively (table 3 ).

\section{DISCUSSION}

The retardation of postprandial glucose absorption is beneficial in diabetes mellitus prevention and care. Inhibition of alpha-amylase and alpha-glucosidase, the enzymes involved in the starch digestion and absorption, is one of the therapeutic approaches for reducing postprandial hyperglycemia. In this in vitro study, S. acuta, A. indicum and $M$. coromandelianum dichloromethane and methanolic fractions of the root, stem and leaf parts demonstrated an appreciable inhibitory activity on alpha-amylase from porcine, alpha-glucosidase from Saccharomyces cerevisiae and from rat intestine compared to 1-deoxynojirimycin and acarbose. Polar compounds were abundant in these plant materials due to higher yields of methanolic fractions than dichloromethane fractions. However, dichloromethane fractions showed stronger yeast alphaglucosidase inhibition than methanolic fraction. For rat intestinal alpha glucosidase, most methanolic fractions showed stronger inhibitory activity except $M$. coromandelianum root and leaf parts. Arciniegas et al. showed that the acetone extracts of $S$. acuta and $S$. rhombifolia aerial parts had potent inhibitory activities on alpha-glucosidases from Saccharomyces cerevisiae and rat intestine. Para-hydroxyphenethyl trans-ferulate and beta-sitosteryl glucopyranoside isolated from these Sida spp. were reported as active compounds [8]. For alpha-amylase, most dichloromethane fractions had stronger inhibitory activity than methanolic fractions except the stems of $A$. indicum and $M$. coromandelianum. The phytochemical study of $M$. coromandelialeaf by Aderogba et al. was performed using $80 \%$ methanol extraction then successive partitioning with n-hexane, dichloromethane, ethyl acetate, nbutanol and water respectively. The ethyl acetate and n-butanol fractionation afforded apigenin-7-0- $\beta-6^{\prime}$ (p-coumaroyl)-glucopyranoside and apigenin-8-C-glucopyranoside (vitexin) [9]. Vitexin was revealed for potent alpha-glucosidase inhibitory activity in vitro [10].

\section{CONCLUSION}

This in vitro studies of $S$. acuta, A. indicum, M. coromandelianum fractional extracts demonstrated the appreciable inhibitory activities on porcine $\alpha$-amylase, yeast $\alpha$-glucosidase and rat intestinal $\alpha$-glucosidase enzymes involved in starch absorption. The results contributed the use in traditional medicine and provided scientific information to continually validate the potential of these Malvaceous plants.

\section{ACKNOWLEDGEMENTS}

The authors are thankful to College of Public Health Sciences, Chulalongkorn University fornecessary assistance and instrumental support. N. D. wishes to express gratitude to Graduate School, Chulalongkorn University, for providing her research scholarship.

\section{FUNDING}

The $90^{\text {th }}$ Anniversary Chulalongkorn University Fund (Ratchadaphiseksomphot Endowment Fund)

\section{AUTHORS CONTRIBUTIONS}

All the authors have contributed equally.

\section{CONFLICT OF INTERESTS}

\section{Declared none}

\section{REFERENCES}

1. Gray GM. Starch digestion and absorption in nonruminants. J Ntur 1992;122:172-7.

2. Dinda B, Das N, Dinda S, Dinda M, Silsarma I. The genus Sida L.A traditional medicine: its ethnopharmacological, phytochemical and pharmacological data for commercial exploitation in herbal drugs industry. J Ethnopharmacol 2015;176:135-76.

3. Arya A, Abdullah MA, Haerian BS, Mohd MA. Screening for hypoglycemic activity on the leaf extracts of nine medicinal plants: in vivo evaluation. J Chem 2012;9:1196-205.

4. Okwuosa CN, Azubike NC, Nebo II. Evaluation of the antihyperglycaemic activity of crude leaf extracts Sidaacuta in normal and diabetic rabbits. Indian J Novel Drug Delivery 2011;3:206-13.

5. Krisanapun C, Lee SH, Peungvicha P, Temsiririrkkul R, Baek SJ. Antidiabetic activities of Abutilon indicum (L.) sweet are mediated by enhancement of adipocyte differentiation and activation of the GLUT1 promoter. Evid Based Complement Alternat Med 2011. DOI:10.1093/ecam/neq004.

6. Peungvicha P, Krisanapun C, Temsiririrkkul R, Wongkrajang Y. Aqueous extract of Abutilon indicum sweet inhibits glucose absorption and stimulates insulin secretion in rodents. Nutr Res 2009;29:579-87.

7. Deore AB, Chavan PN, Sapakal VD, Naikwade NS. Antidiabetic and antihyperlipidemic activities of Malvastrumcoromandelianum Linn leaves in alloxan-induced diabetic rats. Int J Pharmtech Res 2012;4:351-7.

8. Arciniegas A, Perez Castorena AL, Nieto Camacho A, Kita Y, Vivar AR. Anti-hyperglycemic, antioxidant, and antiinflammatory activities of extracts and metabolites from Sidaacuta and Sidarhombifolia. Quimica Nova 2017;40:176-81.

9. Aderogba MA, Madikizela B, Mcgaw LJ. Bioactive constituents from Malvastrumcoromandelianum (L.) garcke leaf extracts. S Afr J Bot 2019;126:371-6.

10. Mengting $\mathrm{Ni}$, Xing Hu, Deming Gong, Guowen Zhang. Inhibitory mechanism of vitexin on $\alpha$-glucosidase and its synergy with acarbose. Food Hydrocoll 2020;105:105824. 